\title{
Predicting Thalasso Tourist Delight: A Hybrid SEM-Artificial Intelligence Analysis
}

\author{
Agustín J. Sánchez-Medina $\mathbb{D}^{1},{ }^{1}$ Ylenia I. Naranjo-Barrera $\left(\mathbb{D},{ }^{2}\right.$ Jesús B. Alonso $\left(\mathbb{D},{ }^{3}\right.$ \\ and Julio Francisco Rufo Torres $\left.{ }^{3}\right)^{3}$ \\ ${ }^{1}$ Instituto Universitario de Ciencias y Tecnologías Cibernéticas (IUCTC), University of Las Palmas de Gran Canaria, \\ Despacho C-2.21, Ed. de Económicas y Empresariales, Campus de Tafira, 35017 Las Palmas de Gran Canaria, Spain \\ ${ }^{2}$ Instituto Universitario de Ciencias y Tecnologías Cibernéticas (IUCTC), University of Las Palmas de Gran Canaria, \\ Campus de Tafira, 35017 Las Palmas de Gran Canaria, Spain \\ ${ }^{3}$ Instituto para el Desarrollo Tecnológico y la Innovación en Comunicaciones (IDeTIC), University of Las Palmas de Gran Canaria, \\ Campus de Tafira, 35017 Las Palmas de Gran Canaria, Spain
}

Correspondence should be addressed to Agustín J. Sánchez-Medina; agustin.sanchez@ulpgc.es and Ylenia I. Naranjo-Barrera; ynaranjobarrera@gmail.com

Received 27 May 2018; Revised 12 August 2018; Accepted 29 August 2018; Published 16 October 2018

Academic Editor: Jorge Arenas-Gaitán

Copyright () 2018 Agustín J. Sánchez-Medina et al. This is an open access article distributed under the Creative Commons Attribution License, which permits unrestricted use, distribution, and reproduction in any medium, provided the original work is properly cited.

\begin{abstract}
This study focuses on the influence of the quality of services received by thalassotherapy customers on their global satisfaction and the relationship between this and the word of mouth. This study uses a hybrid SEM-classification tree analysis. The empirical findings reveal a significant relationship between the quality of each offered service and global satisfaction. This study contributes to identify tourist's satisfaction or delight on received thalasso services through a proposed methodology. The main contribution of this work consists of the proposal of a methodology to identify objectively through the opinion of tourists if they were satisfied or had reached delight. This work demonstrates, confirming what has been found in previous literature, that global satisfaction is related to the different experiences provided by the service. Thus, all hypotheses are accepted, supporting the hypotheses that relate the pool, the staff, the treatments, and the environment to satisfaction. In addition, the hypotheses that link satisfaction with the word of mouth are also supported. This theoretical implication has important practical implications for managers of the type of facilities such as those studied in this paper, since it shows that it is not enough to do well in one of the services provided if the environment or the interaction with the staff is not right.
\end{abstract}

\section{Introduction}

The concept of well-being has its origin in the work of Halbert Dunn in 1959, in which he discusses a particular state that incorporates a general sense of well-being that is formed by the body, mind, spirit, and surrounding environment $[1,2]$. Since old times, health has been known as a motivation to travel. We can mention examples like the Roman terms, the Turkish baths, the Japanese onsens, or nowadays the Alpine healing resorts [3]. However, in recent years, health tourism has reinvented itself and grown in popularity, becoming a tourist phenomenon worldwide with an upward trend that seems to be maintained [4]. Scholars like
Goodarzi et al. [5] believe that this trend is due to the growing awareness of the importance of health in the middle and upper middle classes.

According to Dimitrovski and Todoroviic [6], definitions of health and wellness tourisms are inconsistent and vary significantly, which means that the concept can be understood in different ways. Moreover, this inconsistency is even found in the term itself, and according to the authors, "health tourism," "thermal tourism," and "wellness tourism" are used interchangeably.

Other authors like Mueller and Kaufmann [2] establish different categories for this type of tourism, dividing it into illness $\mathrm{spa} /$ convalescence tourism and prevention tourism, 
the latter being divided into specific illness prevention and wellness tourism. However, on many occasions, wellness centers offer all these services together, and thus, making distinctions between them is not easy.

Therefore, health and wellness tourisms include all the relationships and phenomena that result from a trip with a stay of at least one night, and in which the main motivation is to preserve or promote health and well-being $[2,5,7]$.

Bennett et al. [8] believe that any type of tourism aimed at reducing stress can be considered as a type of health or wellness tourism. If we consider Wray et al. [9], we must note that they emphasize that this traditional way of contemplating health tourism has recently expanded itself to include other types such as yoga, spiritual pilgrimages, or holistic tourism. In this sense, [10] defines it as "the trip of at least one night in a facility that is specifically designed for physical, psychological, spiritual, and/or social welfare enhancement."

This research focuses on the study of tourist's satisfaction and delights in a particular wellness service: thalassotherapy. Etymologically, thalassotherapy comes from the Greek terms "thalassa" and "terapia," these mean sea and therapy [11]. According to the Spanish Society of Thalassotherapy, this is a method of therapy that has been used since ancient times for therapeutic purposes. The most important aspects are the properties that have the chemical elements of sea water, seaweed, mud, and other elements extracted from the sea for health and physical appearance.

Ortiz [11] defines thalassotherapy as "a treatment technique that combines seawater baths (hydrotherapy), marine climate (atherapy), and solar radiation (heliotherapy) bringing benefits to healthy and sick individuals." Since the Greek-Roman period, there is knowledge of these types of treatments. During the Middle Ages, their use decay, but from the eighteenth century onwards, they recover their interest. We find the first traces of thalassotherapy in the tourism sector in the $19^{\text {th }}$ century with the development of large health villas [12].

On one hand, consumer satisfaction is a matter of interest for academic research [13]. The study of the satisfaction of tourists has gained great relevance and topicality in the last years. In this sense, according to Google Scholar, of the 841 researches that have been published with the topic "tourist satisfaction" in the title, $90 \%$ of them have been put forth in the last decade (data obtained the first week of July 2016). If we carry out the same operation in Web of Science, the results are quite similar. It is important to highlight the fact that of the total of 151 investigations that appear in the search, 92\% have been written in the last ten years. Scholars like Choi and Chu [13] confirmed that research on customer satisfaction in the service industry had increased significantly in recent years. On the other hand, if we focus on wellness and tourism, the results obtained show that their study has lately grown. However, the number of documents is considerably lower, 151 researches in Google Scholar (88\% published in the last decade) and 32 studies in Web of Science (96\% published in the last decade).

The importance of this research is based on the different topics we mention below. It is framed in tourism, an economic sector that has developed a great importance in the last decades. It is focused on a specific touristic service, the wellness area. This field has not been studied in depth. Studies about thalassotherapy centers do not abound, so the literature about it is limited.

Therefore, this document has as main purpose to determine how the services offered in thalassotherapy, its personnel, and its facilities influence the satisfaction of the client and how the satisfaction is related to the word of mouth (wom) recommendation. Another important aspect of this work is how to predict the delight through artificial intelligence starting from the variables that influenced satisfaction. It was assumed that there was happiness when people gave the highest score to each item on the overall satisfaction scale, and in addition, they also did it on all of the word of mouth scale.

The results obtained in this study have helped to develop an objective methodology which identifies and evaluates tourist's conditions after receiving thalassotherapy treatments. This way, we have a tool to know if they have felt satisfaction or if they have reached delight. This last status is related by scholars with the highest rate of repetition and with the word of mouth.

The present essay is divided in four chapters. In the first chapter, we make a presentation of the state of the art and of the hypothesis of this research. In the second chapter, the development of the methodology applied during the essay is dealt with. In the third chapter, obtained results are shown, and a short discussion is presented. Finally, in the last chapter, the main conclusions of the research are offered.

\section{Theoretical Background}

In large service industries, customer satisfaction is seen as a key element $[14,15]$. Thus, customer satisfaction or the lack of it could serve as a control mechanism for companies to identify which attributes should improve to achieve this satisfaction [15]. Rajaguru and Hassanli [16] affirm that the quality of the service is considered an important predictor of success in the tourism industry. In addition, it must be considered that, in order to have good results, continuous customer feedback must be made on this variable $[17,18]$.

Although quality of service and satisfaction are related concepts $[16,19,20]$, they are different. Thus, Parasuraman et al. [21] define the quality of services as a judgment related to the superiority of the service. Ryan [22] asserts that quality in the tourism industry is the features and characteristics of services and products that meet the needs of tourists, whether they are declared or implied. Finally, Prayag [23] adds that the quality of the service is an enduring construct that encompasses quality performance in all activities carried out by management and employees.

Satisfaction can be defined as the general assessment that the client makes of the service once it has been consumed [15], being a consequence of the quality of the service [24]. On the other hand, Anderson et al. [25] assert that satisfaction is the result of the general evaluation that derives from the total experience of consumption with a good or service. Cong [26] and Ramamoorthy et al. [27] affirm that this concept is related to the difference between the expectations that 
were held before the consumption of the service and the perceived performance once it was consumed. Thus, in the tourism sector, if the expectations are exceeded, the tourist will be satisfied [24]. In addition, it must be taken into account that the relationships between companies and customers have changed and they must strive to achieve customer satisfaction. To do so, companies must compete in order to provide higher quality services that lead them to achieve the tourist satisfaction [27].

Satisfaction is a very important aspect in the tourism area [28], and it is also a matter of interest for scholars $[13,29]$. Thus, in a changing and dynamic environment, providing quality services to their customers becomes an important tool for suppliers to maintain the competitive advantage [30]. In this way, increasing satisfaction allows to improve the retention and, with that, to increase the profits, to generate a word of mouth, and to expend less in marketing [31]. Thus, it has been related, among other positive aspects, with the fidelity and intention to repeat of the tourist [32-35], with the word of mouth [30, 36, 37] or with paying premium prices $[33,38]$.

For Ifie et al. [39], one of the most important sources of new customers for companies is the recommendations of current customers. This form of promotion is interesting, for companies, because of the low cost it has. In this way, wom is an effective way to promote products and services $[40,41]$. Thus, marketing professionals have not been oblivious to this issue and the implications it has on the results of the company [42]. For Sivadas and Jindal [15], the wom can be defined as the transmission of experiences from person to person that does not originate commercially with respect to a brand or service, being perceived as more credible than advertising; for its part, Saleem et al. [43] state that the wom refers to communications between clients, talking about their experiences and evaluating a service.

Determining what causes a positive wom is of great interest and has been analyzed from different perspectives $[39,44]$. In the tourism industry, due to its fragmented structure, it is of special interest since the acquisition of new clients depends on the references of existing satisfied consumers, generated in the form of a positive wom [15]. According to Ifie et al. [39] or Sivadas and Jindal [15], some of these antecedents of the wom have been issues such as the characteristics of the product and the organization, the relations with the client, the brand image, or the quality of the service which is the most analyzed in the literature [15].

\section{Research Hypothesis}

Satisfaction can be defined as the positive reaction of customers to a specific experience with a product or service [45]. Other authors go further by asserting that it is the reaction to a set of experiences and not just a single one $[33,35]$. As expressed by McDougall and Levesque [31], customer satisfaction has to do with a global evaluation of the service provider. Besides, $\mathrm{Hu}$ et al. [30] consider it as the affective reaction that occurs as a result of one or several services received, which would cover the two previous points of view. In this sense, the overall satisfaction of the tourist in the thalassotherapy centers can come from the satisfaction with the main activities: water treatments in the swimming pools, the personal treatments (body or facial treatments), the environment, and the interaction with the staff. For this reason, the following four hypotheses are formulated:

H1: Satisfaction with swimming pool treatments is positively related to overall satisfaction with the thalassotherapy center

H2: Satisfaction with body treatments is positively related to overall satisfaction with the thalassotherapy center

H3: Satisfaction with the thalassotherapy environment is positively related to overall satisfaction with the thalassotherapy center

H4: Satisfaction with thalassotherapy staff is positively related to overall satisfaction with the thalassotherapy center

According to Saleem et al. [43], the intentions of wom list several factors, among which is the quality of service as one of the most important [39]. In this way, in the tourism industry, there is a link between customer satisfaction and their tendency to share their experiences with positive recommendations $[15,16,34,35,46-50]$. So, according to Lai and Hitchcock [51], the relationship between quality of service and the wom is well confirmed in previous studies. In the same line, Meng and Han [24] assert that wom is a direct result of satisfaction and that this relationship is well supported in the literature. First of all, we propose that the satisfied customers can contribute positively to a positive word of mouth (wom) promotion.

Therefore, the fifth hypothesis of this work is formulated.

H5: Overall satisfaction with the thalassotherapy center is positively related to a favourable word of mouth (wom)

According to Liu and Keh [29], in the last decades, the interest in the emotional states of the consumers has increased. Among these emotional states, delight stands out $[29,52,53]$. It is important to note that delight and satisfaction are not the same [54, 55]. Thus, mere customer satisfaction is not enough to achieve their delight [56]. Following Finn [57], satisfaction and delight do not have exactly the same effects on behavioral intentions, and he suggests that existing research on satisfaction cannot be applied in full to delight. Thus, it can be considered that there are three levels along the continuum of satisfaction: the area of no satisfaction, mere satisfaction, and delight [29]. There must be high satisfaction and an emotional response for delight to exist [58]. Liu and Keh [29] believe that delight is defined by managers in a pragmatic way as what goes beyond satisfaction. However, academics define it as a pleasant surprise. Following this argumentation, Chandler [59] states that it occurs when the customer experiences an unexpected level of value or satisfaction. Likewise, Berman [60] considers that delight requires an extraordinary service or performance of 
the product. Arnold et al. [61] and Rust and Oliver [62] argue that it is a positive emotional state resulting from the positive improvement of the consumer's expectations and the existence of a degree of surprise. Delight can be defined as a positive effect with a high level of activation in which there is a combination of satisfaction with excitement and pleasure $[63,64]$. Thus, delight is generated by a combination of positive disconfirmation and surprise to some previous expectations [55]. It means that it happens when the expectations are positively exceeded with a degree of surprise, so consumers do not expect the product or service to be so good [65].

As believed by Liu and Keh [29] and Berman [60], moving consumers from the satisfaction zone to the delight area is very positive for the company in terms of getting better results in customer retention and sales, word of mouth, and market share. In addition, it increases the value of the brand and the ability to resist the entry of new bidders [60].

To sum up, it should be noted that the tourism sector has not been excluded from research on delights, as has been studied, for example, in hotels [66], restaurants [67], or theme parks $[55,68]$. In the second part of this paper, a proposal is to study the importance of satisfaction with the environment of the establishment, the interaction with the staff, and the main offered activities. Thus, a methodology will be provided that, through classification trees, allows to identify and evaluate objectively the importance that the aforementioned variables have to achieve.

\section{Methodology}

In the elaboration of the present research, both primary and secondary sources of information were used. Secondary ones were used to elaborate the theoretical framework and formulate the hypotheses. The primaries, to validate the hypotheses mentioned above.

4.1. Sample. The sample used to carry out this study was tourists using a well-known Thalasso Hotel located in the south of Gran Canaria, one of the main tourist areas of the Canary Islands, Spain. This 4-star hotel has one of the largest thalassotherapy centers in Europe. It has an area of approximately $7000 \mathrm{~m}^{2}$ focused on health with sea water. The thalassotherapy center offers health and wellness treatments, including massage techniques, body treatments (peeling and wrapping), facials, wellness cures, and hydrotherapy [69].

Questionnaires were used to collect information from the Thalasso visitors. Tourists were informed of the purpose of this work. Data was collected as tourists had just finished their treatment. Surveys were conducted in June 2016.

In total and after eliminating several of them because they were poorly completed, 246 valid questionnaires were obtained. The description of the main characteristics of this sample is reflected in Table 1 . Thus, the majority of the respondents, more than $75 \%$, were Spanish, British, or German nationalities which are the main visitors of the hotel. As for sex, approximately $60 \%$ were men, and the remaining $40 \%$ were women. Finally, it should be mentioned that the majority of respondents were less than 50 years old.
TABle 1: Demographic profile of the respondents.

\begin{tabular}{|c|c|c|}
\hline Variables & Frequency & Percentage \\
\hline \multicolumn{3}{|l|}{ Age } \\
\hline$\leq 30$ & 78 & $31.7 \%$ \\
\hline $31-40$ & 67 & $27.2 \%$ \\
\hline $41-50$ & 30 & $12.2 \%$ \\
\hline $51-60$ & 56 & $22.8 \%$ \\
\hline$\geq 61$ & 15 & $6.1 \%$ \\
\hline \multicolumn{3}{|l|}{ Gender } \\
\hline Male & 149 & $60.6 \%$ \\
\hline Female & 97 & $39.4 \%$ \\
\hline \multicolumn{3}{|l|}{ Nationality } \\
\hline German & 35 & $14.2 \%$ \\
\hline Argentinian & 4 & $1.6 \%$ \\
\hline Austrian & 2 & $0.8 \%$ \\
\hline Brazilian & 4 & $1.6 \%$ \\
\hline British & 48 & $19.5 \%$ \\
\hline Czech & 4 & $1.6 \%$ \\
\hline Spanish & 104 & $42.3 \%$ \\
\hline French & 15 & $6.1 \%$ \\
\hline Hungarian & 2 & $0.8 \%$ \\
\hline Irish & 5 & $2.0 \%$ \\
\hline Mexican & 2 & $0.8 \%$ \\
\hline Portuguese & 2 & $0.8 \%$ \\
\hline Russian & 7 & $2.8 \%$ \\
\hline Swedish & 4 & $1.6 \%$ \\
\hline Swiss & 4 & $1.6 \%$ \\
\hline Indian & 2 & $0.8 \%$ \\
\hline Polish & 2 & $0.8 \%$ \\
\hline Total & 246 & \\
\hline
\end{tabular}

4.2. Measurements. In the present study, the method used to obtain the necessary information to cover the objectives was the survey, in which the basic observation instrument is the questionnaire [70]. Except for age, sex, nationality, level of education, and place of residence, all items in this study are scored on a 7-point Likert scale ranging from (1) "strongly disagree" to (7) "totally agree." The survey questions were written in Spanish, English, and German.

Besides, the scales to evaluate the services offered by the Thalasso, i.e., the hydrotherapy circuit, the individual treatments (body or face), and the general environment, in addition to the satisfaction with the staff and global satisfaction were elaborated based on the proposal by Huang et al. [71]. To this, we have to add that the word of mouth scale was elaborated based on the work of Riquelme et al. [72].

4.3. Data Analysis. Data analysis has been divided into two parts. The first part has been used to test the hypotheses that related the quality of the services with global satisfaction. For this purpose, structural equations based on covariance were used. This is done using the lavaan R package [73]. Once the proposed model was validated, a methodology was 
TABLE 2: Reliability, convergent validity, and discriminant validity: correlation coefficients and chi-square difference test.

\begin{tabular}{|c|c|c|c|c|c|c|c|c|c|}
\hline $\begin{array}{l}\text { Cronbach's } \\
\text { alpha }\end{array}$ & $\begin{array}{c}\text { Composite } \\
\text { reliability }\end{array}$ & AVE & Construct & $\begin{array}{c}\text { Body } \\
\text { treatment }\end{array}$ & $\begin{array}{l}\text { Human } \\
\text { resources }\end{array}$ & $\begin{array}{c}\text { Pool } \\
\text { treatment }\end{array}$ & Environment & Satisfaction & wom \\
\hline 0.915 & 0.916 & 0.785 & Treatment & 0.886 & & & & & \\
\hline 0.868 & 0.871 & 0.693 & Staff & $\begin{array}{c}0.222^{* * *} \\
\left(9.831^{* *}\right) \\
\# 0.220 \#\end{array}$ & 0.833 & & & & \\
\hline 0.944 & 0.944 & 0.809 & Pool & $\begin{array}{c}0.698^{* * *} \\
\left(153.53^{* * *}\right) \\
\# 0.702 \#\end{array}$ & $\begin{array}{c}0.259^{* * *} \\
\left(13.913^{* * *}\right) \\
\# 0.268 \#\end{array}$ & 0.900 & & & \\
\hline 0.950 & 0.950 & 0.825 & Environment & $\begin{array}{c}0.615^{* * *} \\
\left(99.324^{* * *}\right) \\
\# 0.614 \#\end{array}$ & $\begin{array}{c}0.352^{* * *} \\
\left(26.953^{* * *}\right) \\
\# 0.338 \#\end{array}$ & $\begin{array}{c}0.749^{* * *} \\
\left(174.52^{* * *}\right) \\
\# 0.750 \#\end{array}$ & 0.908 & & \\
\hline 0.955 & 0.954 & 0.874 & Satisfaction & $\begin{array}{c}0.760^{* * *} \\
\left(166.61^{* * *}\right) \\
\# 0.756 \#\end{array}$ & $\begin{array}{c}0.396^{* * *} \\
\left(31.651^{* * *}\right) \\
\# 0.376 \#\end{array}$ & $\begin{array}{c}0.762^{* * *} \\
\left(173.62^{* * *}\right) \\
\# 0.754 \#\end{array}$ & $\begin{array}{c}0.793^{* * *} \\
\left(204.76^{* * *}\right) \\
\# 0.778 \#\end{array}$ & 0.935 & \\
\hline 0.963 & 0.963 & 0.897 & wom & $\begin{array}{c}0.601^{* * *} \\
\left(126.75^{* * *}\right) \\
\# 0.668 \#\end{array}$ & $\begin{array}{c}0.313^{* * *} \\
\left(43.728^{* * *}\right) \\
\# 0.434 \#\end{array}$ & $\begin{array}{c}0.602^{* * *} \\
\left(158.66^{* * *}\right) \\
\# 0.722 \#\end{array}$ & $\begin{array}{c}0.627^{* * *} \\
\left(137.08^{* * *}\right) \\
\# 0.671 \#\end{array}$ & $\begin{array}{c}0.791^{* * *} \\
\left(194.38^{* * *}\right) \\
\# 0.774 \#\end{array}$ & 0.947 \\
\hline
\end{tabular}

Note: $n=246 ;{ }^{* * *} p \leq 0.001 ;{ }^{* *} p \leq 0.01$; square root of AVE (in bold) is shown on the diagonal; off-diagonal elements are the correlation coefficients; values in brackets show the chi-square difference statistics with $d f=1$; values in \# show the ratio of heterotrait-monotrait correlations.

developed to objectively identify and evaluate whether the clients were satisfied or had reached delight (second part). To do this, we used as input data the opinion of the tourists about the different services, the environment of the facilities, and the interaction with the staff. It should be mentioned that there was delight when people gave the highest score to each item on the overall satisfaction scale and, in addition, they also did it on all of the word of mouth scale. All this was implemented with the assembly of classification trees, specifically using the techniques of bagging and boosting. For this purpose, adabag software was used [74].

\section{Results}

5.1. Contrast of Hypotheses. As it can be seen in Table 2, there is no occurrence of multicollinearity $[75,76]$ because all the correlation coefficients are below 0.8 and also the largest variance inflation factor (VIF) is $3.366(<10)$. As recommended by Hair et al. [77], Leong et al. [78], and Wang et al. [79], a two-step technique was used to examine the causal relationship between the constructs. First, an exploratory factorial analysis, which was useful for filtering and defining the dimensional character of the scale [80], was used. The second stage was a confirmatory factor analysis to evaluate the validity of constructs $[81,82]$.

To evaluate the convergent validity, the estimated load of each indicator in its construct was examined. For such validity, the load must be high, and the values of $t$ statistically must be significant [83]. In the planned model, the above is confirmed with an acceptable convergent validity. Thus, the AFC results indicate that the relationship between each item and its respective construct is statistically significant with loads that exceed 0.790 (all $p$ value $\leq 0.001$ ). With these results, the existence of convergent validity is assumed (see Table 3). It is also necessary to determine the convergent validity of the constructs. According to Hair et al. [84] and
Roldán and Sánchez-Franco [85], this validity must be evaluated by analyzing Cronbach's alpha, the composite reliability index by Fornell and Larcker [86], and the average extracted variance (AVE). The reference point, for the first two cases, is 0.7 and for the third case is $0.5[84,85]$. In the model we considered and as shown in Table 2, all these criteria are well met. Thus, the minimum Cronbach's alpha value obtained is 0.868 , the composite reliability is 0.871 , and the AVE, 0.693. Therefore, it can be concluded that the reflective constructs are consistent.

To obtain the discriminant validity, the square root of the AVE (located on the diagonal of the matrix in Table 2) is compared to the correlations between the constructs (the elements located outside the diagonal) $[85,87]$. On average, it can be observed that each construct is stronger related to its own means than to the other constructs. Also, the chisquare difference test [88] is also achieved, and the result shows that all constructs are different. In addition, it was used on the evaluation of the heterotrait-monotrait ratio (HTMT) [89]. This criterion is more demanding than the previous criteria. This measure establishes the ratio of heterotrait-monotrait correlations, with discriminant validity confirmed when the values are less than 0.90 [90]. The highest value obtained in our sample is 0.778 . Consequently, there are no discriminant validity problems even though the correlations between the constructs are high.

5.2. Test of Hypotheses. The structural model was verified with some measures of goodness. To adjust the measurement model, robust maximum likelihood estimators were used $[91,92]$. As it can be seen in Table 4, all of them exceeded the recommended thresholds $(\mathrm{CFI}=0.940, \mathrm{TLI}=0.929$, RMSEA $=0.056$, and SRMR $=0.044)$. Hence, the structural model fits with the collected data.

In the path analysis, the significance of a path is determined based on its $p$ value. The results implied that $77.5 \%$ 
TABLE 3: Confirmatory analyses.

\begin{tabular}{|c|c|c|c|}
\hline Construct/indicator & Standardized loading & $Z$ value & $p$ value \\
\hline \multicolumn{4}{|l|}{ Body treatments } \\
\hline The Thalasso has an adequate number of body care treatments & 0.906 & & \\
\hline The Thalasso offers a wide variety of body care treatments & 0.890 & 23.324 & $\leq 0.001$ \\
\hline I am satisfied with the body care treatments provided by the Thalasso & 0.858 & 21.036 & $\leq 0.001$ \\
\hline \multicolumn{4}{|l|}{ Pool treatments } \\
\hline The "Get in Shape" pool treatments are adequate & 0.911 & & \\
\hline I am satisfied with the "Get in Shape" pool treatments & 0.914 & 23.949 & $\leq 0.001$ \\
\hline The pool programmes are satisfactory & 0.911 & 20.579 & $\leq 0.001$ \\
\hline I am satisfied with the guidance that I was given for the "Get in Shape" pool services & 0.866 & 16.329 & $\leq 0.001$ \\
\hline \multicolumn{4}{|l|}{ Human resources } \\
\hline The staff gives an adequate service to the clients & 0.866 & & \\
\hline The staff gives personal attention to the clients & 0.836 & 13.514 & $\leq 0.001$ \\
\hline The staff is polite to the clients & 0.790 & 8.764 & $\leq 0.001$ \\
\hline \multicolumn{4}{|l|}{ Environment } \\
\hline I think the Thalasso has a comfortable atmosphere & 0.863 & & \\
\hline I am satisfied with the cleanness of the facilities of the Thalasso & 0.887 & 23.028 & $\leq 0.001$ \\
\hline I am satisfied with the decoration, conditions, and style of the Thalasso & 0.955 & 24.839 & $\leq 0.001$ \\
\hline I am satisfied with the security conditions of the Thalasso & 0.925 & 26.676 & $\leq 0.001$ \\
\hline \multicolumn{4}{|l|}{ Satisfaction } \\
\hline The Thalasso has met my expectations & 0.930 & & \\
\hline I am willing to return to the Thalasso & 0.936 & 41.619 & $\leq 0.001$ \\
\hline In general, I am satisfied with the service given at the Thalasso & 0.940 & 24.767 & $\leq 0.001$ \\
\hline \multicolumn{4}{|l|}{ Word of mouth } \\
\hline I would be willing to recommend the Thalasso to someone who sought my advice & 0.944 & & \\
\hline I would be willing to encourage friends and family to use Thalasso & 0.960 & 29.624 & $\leq 0.001$ \\
\hline I would have no problem in saying positive things about the Thalasso & 0.936 & 25.543 & $\leq 0.001$ \\
\hline
\end{tabular}

TABle 4: Measures of the model fit.

\begin{tabular}{lcc}
\hline Number of observations: 246 & & Maximum likelihood \\
\hline Estimator & 301.741 & 279.968 \\
Minimum function test statistic & 159 & 159 \\
Degrees of freedom & $\leq 0.001$ & $\leq 0.001$ \\
$p$ value (chi-square) & & 1.081 \\
Scaling correction factor or the Satorra-Bentler correction & 5648.416 & 2212.795 \\
Model test baseline model & 190 & 190 \\
Minimum function test statistic & $\leq 0.001$ & $\leq 0.001$ \\
Degrees of freedom & Maximum likelihood \\
p value & & Robust \\
& 0.974 & 0.940 \\
User model versus baseline model $_{\text {Comparative fit index (CFI) }}^{\mathrm{a}}$ & 0.969 & 0.929 \\
Tucker-Lewis index (TLI) $^{\mathrm{b}}$ & 0.061 & 0.056 \\
RMSEA $^{\mathrm{c}}$ & 0.044 & 0.044 \\
SRMR $^{\mathrm{d}}$ & & \\
\hline
\end{tabular}

${ }^{\mathrm{a}}$ Recommended value $\geq 0.90$ [77]. ${ }^{\mathrm{b}}$ Recommended value $\geq 0.90$ [77]. ${ }^{\mathrm{c}}$ Recommended value $\leq 0.08$ [78]. ${ }^{\mathrm{d}}$ Recommended value $\leq 0.1$ [78]. 
TABLE 5: Results of path analysis.

\begin{tabular}{|c|c|c|c|c|c|c|}
\hline Hypothesis & Path & Estimate & Std. error & $Z$ value & $p$ value & Remarks \\
\hline H1 & Pool $\rightarrow$ satisfaction & $0.186^{* *}$ & 0.071 & 2.624 & 0.009 & Supported \\
\hline $\mathrm{H} 2$ & Staff $\rightarrow$ satisfaction & $0.132^{*}$ & 0.078 & 2.448 & 0.014 & Supported \\
\hline $\mathrm{H} 3$ & Treatment $\rightarrow$ satisfaction & $0.366^{* * *}$ & 0.067 & 5.739 & $\leq 0.001$ & Supported \\
\hline $\mathrm{H} 4$ & Environment $\rightarrow$ satisfaction & $0.383^{* * *}$ & 0.075 & 5.093 & $\leq 0.001$ & Supported \\
\hline H5 & Satisfaction $\rightarrow$ wom & $0.791^{* * *}$ & 0.086 & 13.745 & $\leq 0.001$ & Supported \\
\hline
\end{tabular}

Significance level: ${ }^{* * *} p \leq 0.001 ;{ }^{* *} p \leq 0.01 ;{ }^{*} p \leq 0.05 ;{ }^{\text {ns }}$ not significant

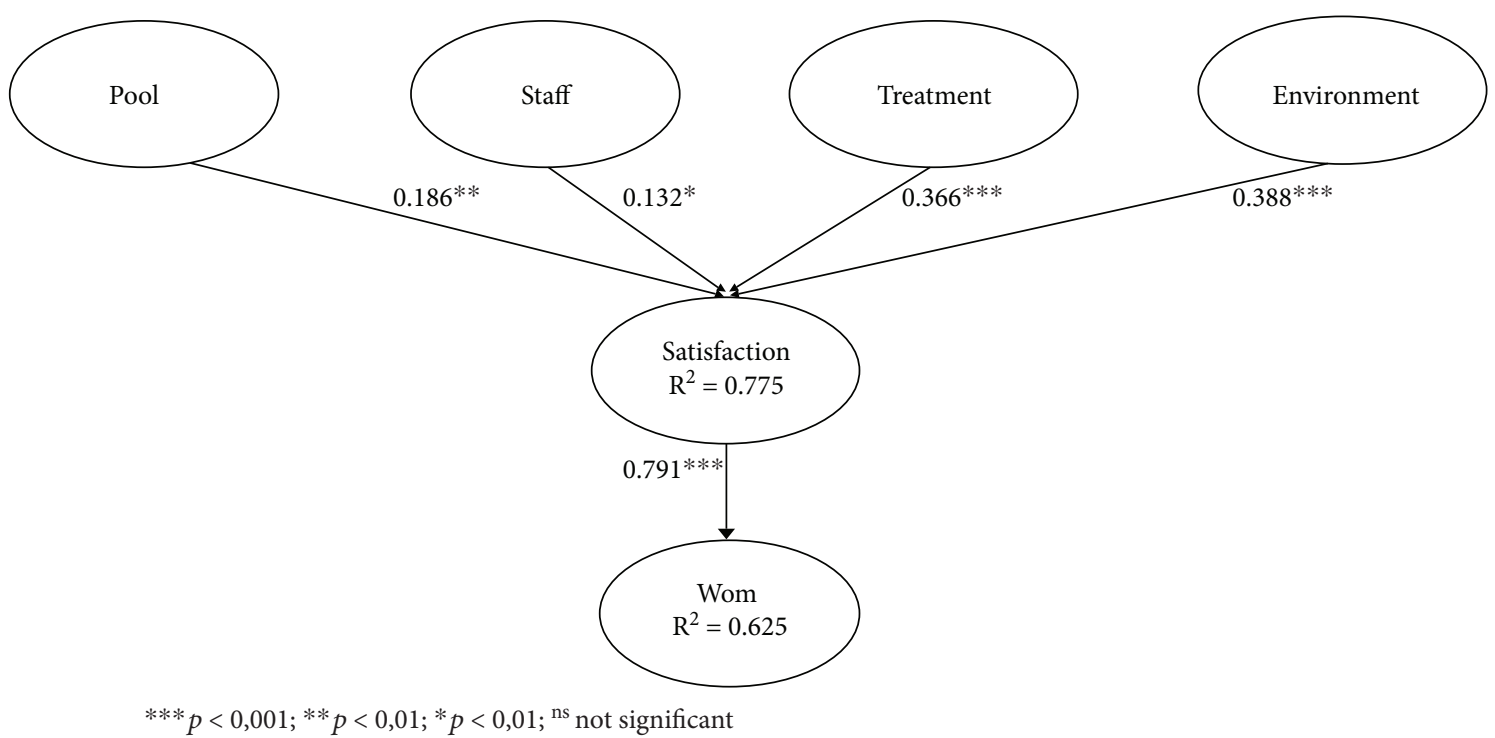

Figure 1: Structural model.

of the variance in satisfaction is explained by the model variables while satisfaction is able to explain $62.5 \%$ of the variance in wom.

As shown in Table 5, the findings further reveal that pool treatments $\left(\beta=0.186^{* *}\right)$, human resources $\left(\beta=0.132^{*}\right)$, body treatments $\left(\beta=0.366^{* * *}\right)$, and environment $\left(\beta=0.383^{* * *}\right)$ have significant and positive impacts on satisfaction while satisfaction $\left(\beta=0.791^{* * *}\right)$ positively impacted on wom. Therefore, all hypotheses were supported (see Figure 1 and Table 5).

5.3. Proposal of a Model to Establish the Importance of the Determinants of Delight in the Services of Thalassotherapy. Based on the previous results, it was decided to include as input variables of the delight classifier the four variables that were significant in the previous model, that is to say, the environment, the service of body treatments, the service of the swimming pool, and the interaction with the staff.

To analyze the data, an artificial intelligence method was used, classification trees were assembled with boosting and bagging [93-96]. Bagging and boosting [74] can generate a diverse set of classifiers through the manipulation of training data with a learning algorithm [97]. The bagging method produces multiple versions of a predictor so that an aggregate predictor can be obtained. These multiple versions are generated by making bootstrap replicates of the learning set [98].

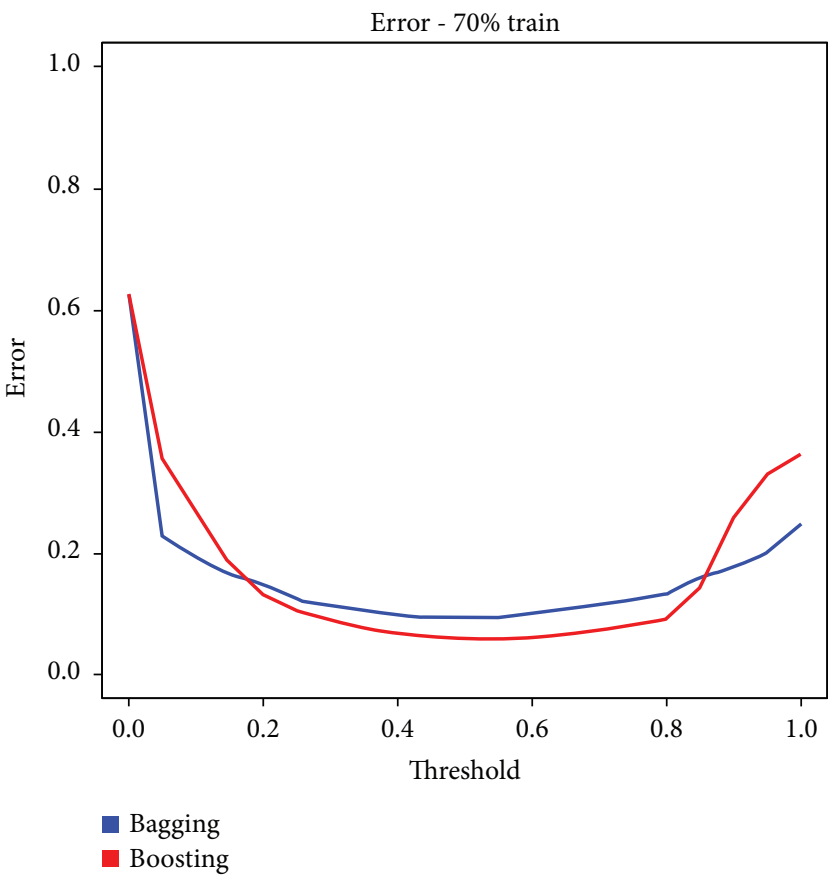

Figure 2: Total error of the models used. 
TABLE 6: Total error of the models used.

\begin{tabular}{lllllllllll}
\hline Threshold & $\mathbf{0 . 0 0 0}$ & $\mathbf{0 . 0 5 0}$ & $\mathbf{0 . 1 0 0}$ & $\mathbf{0 . 1 5 0}$ & $\mathbf{0 . 2 0 0}$ & $\mathbf{0 . 2 5 0}$ & $\mathbf{0 . 3 0 0}$ & $\mathbf{0 . 3 5 0}$ & $\mathbf{0 . 4 0 0}$ & $\mathbf{0 . 4 5 0}$ \\
Bagging & 0.627 & 0.228 & 0.191 & 0.166 & 0.148 & 0.122 & 0.113 & 0.105 & 0.099 & 0.093 \\
Boosting & 0.627 & 0.356 & 0.270 & 0.182 & 0.131 & 0.106 & 0.088 & 0.076 & 0.069 & 0.063 \\
Threshold & $\mathbf{0 . 5 0 0}$ & $\mathbf{0 . 5 5 0}$ & $\mathbf{0 . 6 0 0}$ & $\mathbf{0 . 6 5 0}$ & $\mathbf{0 . 7 0 0}$ & $\mathbf{0 . 7 5 0}$ & $\mathbf{0 . 8 0 0}$ & $\mathbf{0 . 8 5 0}$ & $\mathbf{0 . 9 0 0}$ & $\mathbf{0 . 9 5 0}$ \\
Bagging & 0.093 & 0.094 & 0.101 & 0.106 & 0.114 & 0.122 & 0.132 & 0.160 & 0.176 & 0.201 \\
Boosting & 0.060 & 0.060 & 0.062 & 0.065 & 0.071 & 0.079 & 0.092 & 0.144 & 0.260 & 0.329 \\
\hline
\end{tabular}

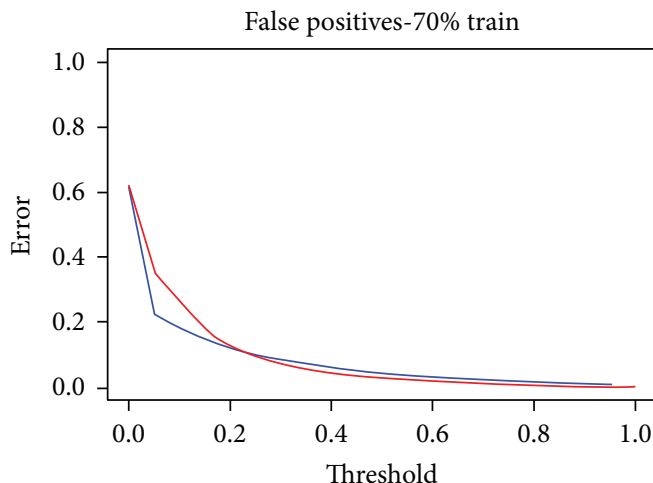

Bagging

Boosting

(a)

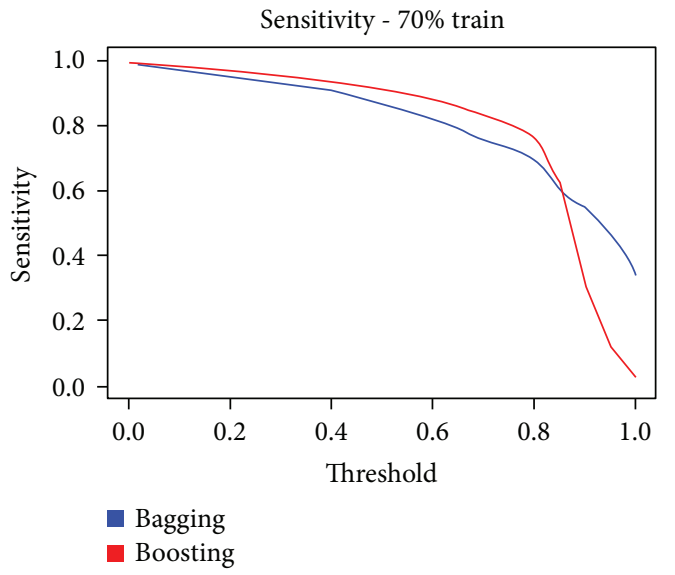

(c)

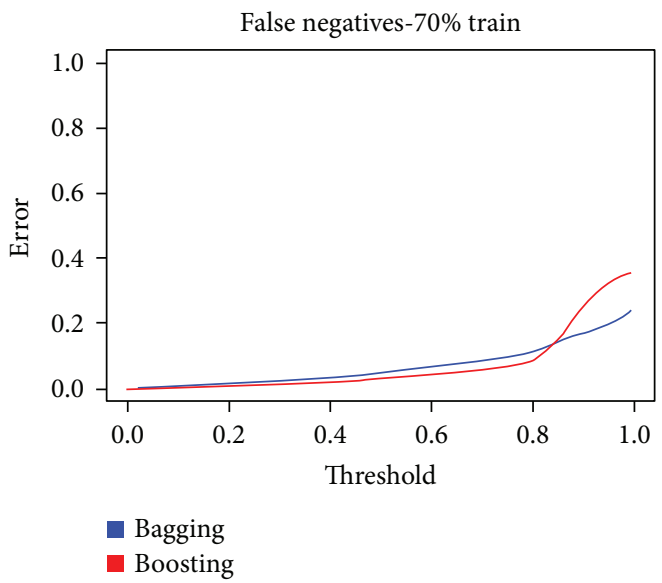

(b)

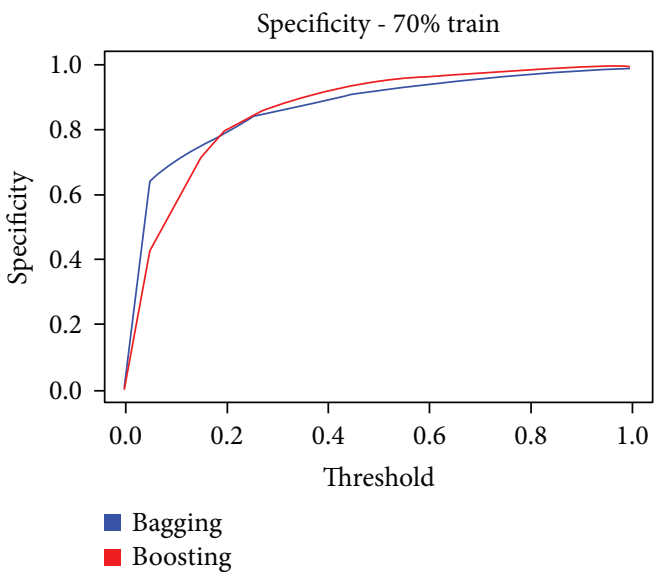

(d)

FIGURE 3: False positives, false negatives, specificity, and sensitivity.

Thus, starting from a training set with $m$ cases, other sets are created (with replacements) [97]. A series of classifiers can be obtained with the boosting technique. The training set for each member of the series is chosen according to the performance of the previous classifier. Thus, the cases are extracted with replacement with probability proportional to their weights [97].

Classification and regression trees are, compared to other learning techniques, one of the most intuitive and transparent classification algorithms [99], representing a powerful alternative to the more traditional statistical models [98]. According to Homaie-Shandizi et al. [100], they were presented during the ' 60 s by Morgan and Sonquist [101], and two decades later, Breiman et al. [102] develop the first exhaustive and modern algorithm. In the tree structure, the leaves represent the classifications and the branches the conjunctions of characteristics that lead to the mentioned categories $[98,103]$. Its purpose is to perform a recursive partition of the training data into homogeneous subsets so that each new partition will minimize the number of members [104]. The technique of the decision trees is attractive for a lot of business applications [99] since a minimum of parameters and no domain knowledge is required. They have the advantage, too, of being able to detect nonlinear relationships and to show a good performance when there is qualitative information [98]. 
As already mentioned in Methodology, the adabag package of $\mathrm{R}$, which allows the use of bagging and boosting for the assembly of classification trees, was used. For its application, $70 \%$ of the sample for training and the remaining $30 \%$ for testing was established. It is worth mentioning that different thresholds for classification were implemented. Thus, values ranging from 0 to 1 were used for this threshold with increments of 0.05. In all, 1000 iterations were performed. In each one of them, which elements of the database would be in the training group and which were in the test group were chosen in a random way. For each of these training and test groups, bagging and boosting were applied, obtaining the results that will be shown below. Once all the results were available, the average value and the standard deviation obtained with the aforementioned 1000 iterations were calculated, for each level of threshold. The $t$ value was also calculated to compare it with a two-tailed Student's $t$ with 998 degrees of freedom.

The results obtained from applying the cited methods will be presented below. The "rough data" produced by a classification system are the counts of the correct and incorrect classifications of each class. A matrix of confusion, which is a contingency table form that shows the differences between the actual and predicted classes for a set of labeled examples [105], is used to analyze the obtained information. Referring to the total error obtained, it can be observed that the smaller errors, which are around 9\% with bagging and $6 \%$ with boosting, occur in both methods with thresholds close to 0.5 (see Figure 2). Table 6 show that the minimum error is obtained using bagging. Errors occurring with the first method are always lower when the threshold is less than 0.20 or higher than 0.85 , that is, in extreme cases.

In addition, Figure 3 shows that for the false positives, that is, cases classified as "delight" that in reality were not "delight," both methods behave similarly. As for specificity, it is worth mentioning that for very low thresholds, the bagging behaves better, occurring otherwise when it exceeds the heat of 0.1. As far as sensitivity is concerned, boosting for all thresholds below 0.85 behaves better. Moreover, an analysis is presented of sensitivity, "the proportion of true positives correctly identified by the test," and specificity, "the proportion of true negatives correctly identified by the test" [106]. (Sensitivity $=$ true positive/(true positive + false negative); specificity $=$ true negative $/($ true negative + false positive)). In relation to sensitivity, boosting always behaves slightly better except when the thresholds are very high; in that case, the bagging provides a better performance. For thresholds higher than 0.15 , boosting presents a better specificity.

In order to show the performance of both methods, the ROC curves obtained for both are presented below. These curves are a good way to visualize the performance of the classifiers [105]. Figure 4 shows that the area under the curve when using boosting is greater than when using bagging.

Regarding the importance given by bagging and boosting to the variables used to classify the companies in the categories "delight" and "nondelight" (see Figure 5), the bootstrapping technique (1000 subsamples) was used to generate the Student $t$ statistics and the standard errors. Thus, the statistical significance of the mean values for importance was obtained. In both methods, it considered as the least

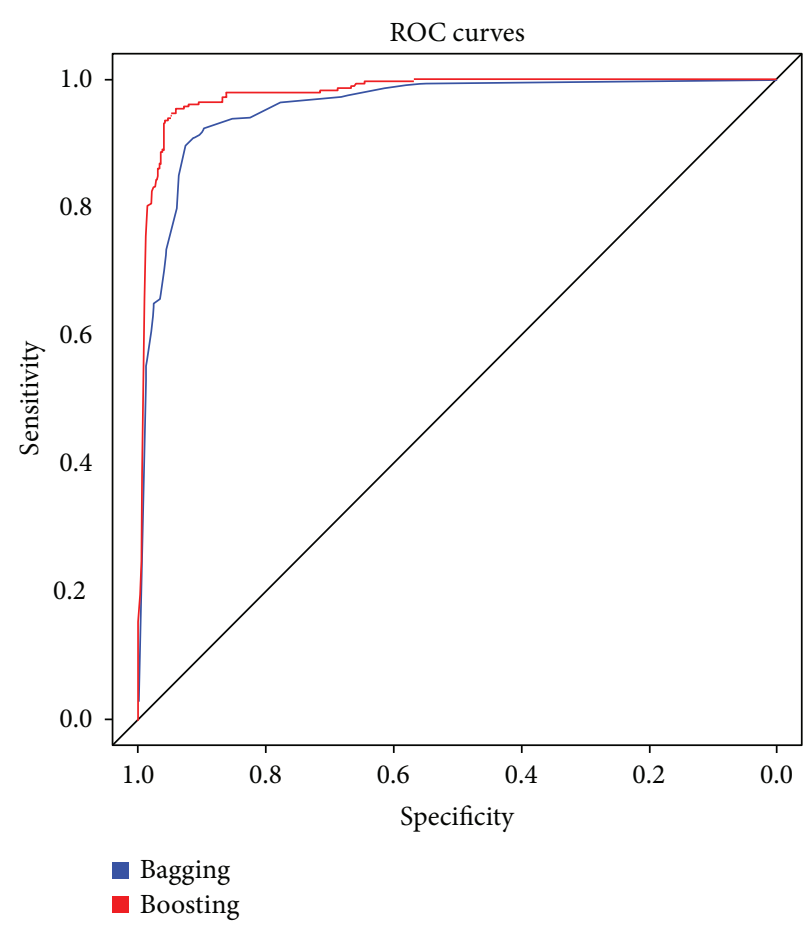

FIgURE 4: ROC curves.

important variable the pool treatments and as the most important the staff. However, there is a slight difference in the situation of those in the second and third positions. Thus, in the boosting, the second in relevance is that of treatment followed by environment, whereas in the bagging, these positions are interchanged (see Table 7).

5.4. Discussion. According to the results, the presented hypotheses are confirmed. The overall satisfaction of the tourist in the thalassotherapy centers comes from the satisfaction with the main activities: water treatments in the swimming pools, the personal treatments (body or facial treatments), the environment, and the interaction with the staff. The results tell us, as well, that the satisfied customers can contribute positively to the word of mouth promotion. This theoretical implication has important practical implications for managers of facilities, such as those studied in this work, since it shows that it is not enough to do well in one of the services provided if the environment or the interaction with the staff is not right. In this case, all the thalasso facilities and the staff interaction must be taken into account by managers to increase the tourist delight. Today's business is characterized by tough competition; consequently, the delivery of a quality service becomes a fundamental element to attract and retain customers [27].

It is a contribution of the present work the proposal of a methodology to identify and evaluate objectively and through the opinion about the different services offered by thalassotherapy if the tourists' status was of satisfaction or had arrived at delight. This is a matter of great importance if we take into account that, as it has been indicated throughout this work, when a customer moves from satisfaction to delight, he 


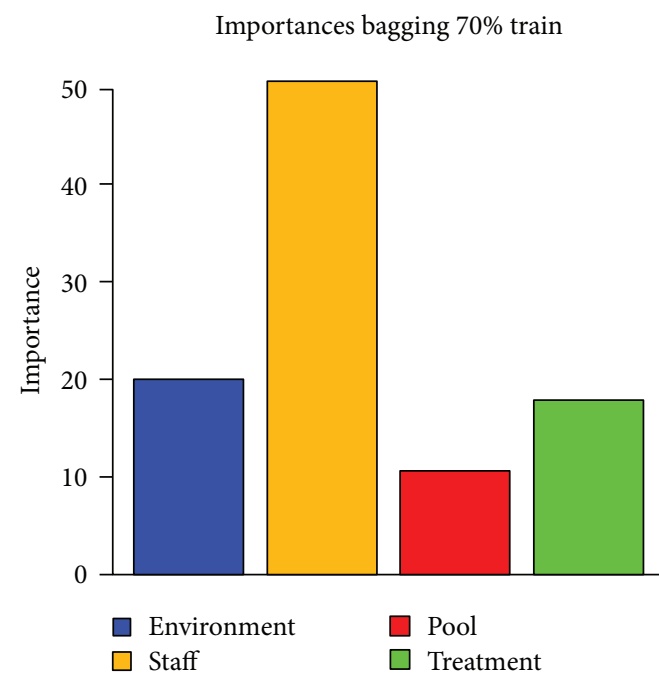

(a)

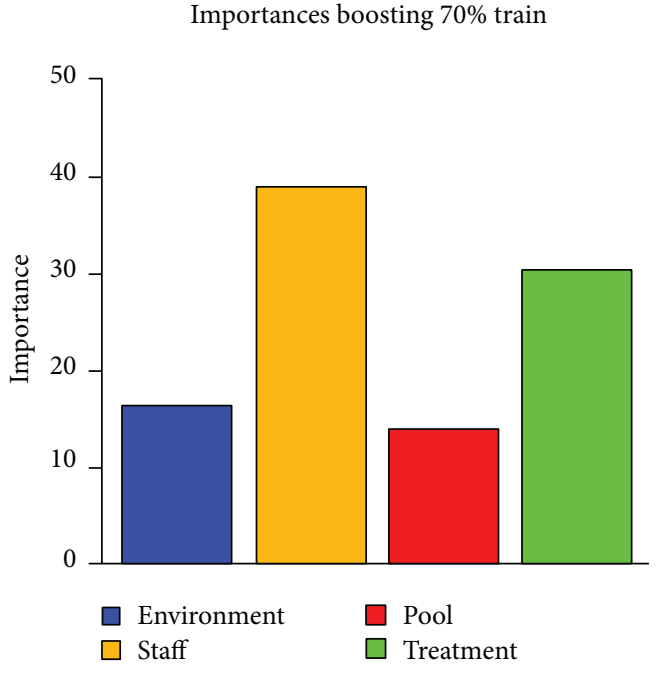

(b)

FIgURE 5: Importance of each of the variables studied for classification.

TABle 7: Means of the importance, standard deviations, and Student $t$ for bagging and boosting.

\begin{tabular}{|c|c|c|c|c|}
\hline & \multicolumn{4}{|c|}{ Bagging } \\
\hline & Environment & Staff & Pool & Treatment \\
\hline Mean importances & $20.272^{* *}$ & $50.865^{* * *}$ & $10.778^{*}$ & $18.085^{* *}$ \\
\hline SD importances & 7.765 & 9.501 & 4.207 & 6.504 \\
\hline \multirow[t]{2}{*}{$t$} & 2.611 & 5.354 & 2.562 & 2.780 \\
\hline & \multicolumn{4}{|c|}{ Boosting } \\
\hline Boosting & Environment & Staff & Pool & Treatment \\
\hline Mean importances & $16.499^{* * *}$ & $39.071^{* * *}$ & $14.129^{* * *}$ & $30.302^{* * *}$ \\
\hline SD importances & 3.360 & 4.513 & 2.732 & 4.467 \\
\hline$t$ & 4.910 & 8.657 & 5.172 & 6.783 \\
\hline
\end{tabular}

Bootstrap- $t$ (based on $t(998)$ two-tailed test); $t(0.001 ; 998)=3.300 ; t(0.01 ; 998)=2.581 ; t(0.05 ; 998)=1.962 ;{ }^{* * *} p<0.001 ;{ }^{* *} p<0.01 ;{ }^{*} p<0.05 ;{ }^{\text {ns }}$ nonsignificant.

contributes to greater profitability to the company, increases its fidelity, and improves its word of mouth [53, 60].

The methodology developed is based on the use of assembled classification trees, specifically with the methods of bagging and boosting. Also, from the comparison of the results obtained with both methods, it was observed that the assembly with boosting provided better results. The great use of machine learning is in situations where the variables are related in a highly nonlinear way. Besides, it is also an academic contribution of this work that the proposed model, if it is frequently fed, can maintain the classifications updated with the tastes of the clients and the conditions of the service provided. So, this kind of artificial intelligence (AI) can make continuous evaluations as we mentioned in the theoretical background of this paper.

Regarding the main weaknesses of the present study, it is worth mentioning that a cross-sectional methodology was used, thus increasing the probability of the study being biased due to the use of a single method/data source. Another limitation is determined by the technique used, structural equations, which assumes a linearity of the relationships between latent variables [77].

\section{Conclusions}

This work demonstrates, confirming what has been found in previous literature $[55,59,68]$, that global satisfaction is related to the different experiences provided by the service. Thus, all hypotheses are accepted, supporting the hypotheses that relate the pool, the staff, the treatments, and the environment to satisfaction. In addition, the hypotheses that link satisfaction with the wom are also supported. This theoretical implication has important practical implications for managers of the type of facilities such as those studied in this paper, since it shows that it is not enough to do well in one of the services provided if the environment or the interaction with the staff is not right. In this way, managers could have a tool that could inform them about which aspects of the business are contributing to a better satisfaction and delight of the clients. In this sense, they can establish corrective actions to improve these variables. In addition, the system can be fed with new data so that managers could always have up-todate information on which of the services provided contributes more, at each moment, to the satisfaction of customers. This is in line with the constant feedback that authors like Lu 
et al. [17] and Mohsin and Lockyer [18] consider necessary in business nowadays. This issue is relevant because in this type of business, the pleasures of customers can change quickly for various issues such as the emergence of new treatments both in the cabin and in the pool or the appearance of new competitors with modern facilities. The conditions in which the service is provided may change, due to deterioration of the facilities, personnel changes or behavior, etc. All this is of great importance since the service companies have become increasingly clear that they must focus on the client side and that the quality of the service is a differentiator on the road to success [27]. In this way, Sivadas and Jindal [15] state that those responsible for marketing in the tourism sector must understand better the factors that drive the intention of wom if they wish to develop effective marketing strategies. Moreover, this is even more important taking into account that the growth of the power of wom comes from the increasing use of social networks [107].

Finally, as far as possible future lines of research are concerned, it has been considered that it would be interesting to go deeper into the search for a shorter scale to measure satisfaction with the different services provided by the hotel, as well as to study if there are cultural differences between the various nationalities in order to reach delight for the service received.

\section{Data Availability}

The data used to support the findings of this study are included within the article.

\section{Conflicts of Interest}

The authors declare that they have no conflicts of interest.

\section{References}

[1] K. H. Chen, F. H. Chang, and F. Y. Liu, "Wellness tourism among seniors in Taiwan: previous experience, service encounter expectations, organizational characteristics, employee characteristics, and customer satisfaction," Sustainability, vol. 7, no. 8, pp. 10576-10601, 2015.

[2] H. Mueller and E. L. Kaufmann, "Wellness tourism: market analysis of a special health tourism segment and implications for the hotel industry," Journal of Vacation Marketing, vol. 7, no. 1, pp. 5-17, 2001.

[3] L. Puczkó and M. Bachvarov, "Spa, bath, thermae: what's behind the labels?," Tourism Recreation Research, vol. 31, no. 1, pp. 83-91, 2006.

[4] E. Alén, P. De Carlos, and T. Domínguez, "An analysis of differentiation strategies for Galician thermal centres," Current Issues in Tourism, vol. 17, no. 6, pp. 499-517, 2014.

[5] M. Goodarzi, N. Haghtalab, and E. Shamshiry, "Wellness tourism in Sareyn, Iran: resources, planning and development," Current Issues in Tourism, vol. 19, no. 11, pp. 10711076, 2016.

[6] D. Dimitrovski and A. Todorović, "Clustering wellness tourists in spa environment," Tourism Management Perspectives, vol. 16, pp. 259-265, 2015.
[7] P. Erfurt-Cooper and M. Cooper, Health and Wellness Tourism, Channel View Publications, Bristol, 2009.

[8] M. Bennett, B. King, and L. Milner, "The health resort sector in Australia: a positioning study," Journal of Vacation Marketing, vol. 10, no. 2, pp. 122-137, 2004.

[9] M. Wray, J. Laing, and C. Voigt, "Byron Bay: an alternate health and wellness destination," Journal of Hospitality and Tourism Management, vol. 17, no. 1, pp. 158-166, 2010.

[10] N. A. Valentine, "Wellness tourism: using tourists' preferences to evaluate the wellness tourism market in Jamaica," Review of Social Sciences, vol. 1, no. 3, 2016.

[11] M. R. Ortiz, "Orígenes y fundamentos de la talasoterapia," Revista de La Facultad de Ciencias, vol. 2, p. 12, 2004, http://www.uax.es/publicacion/origenes-y-fundamentos-dela-talasoterapia.pdf.

[12] Abalnearios, "Abalnearios," 2016, July 2016, http://www. abalnearios.com/talasoterapia/.

[13] T. Y. Choi and R. Chu, "Determinants of hotel guests' satisfaction and repeat patronage in the Hong Kong hotel industry," International Journal of Hospitality Management, vol. 20, no. 3, pp. 277-297, 2001.

[14] Z. Zhang, M. Jiang, and X. Li, "Refining the relationship between attribute performance and customer satisfaction in the Chinese hospitality industry," Total Quality Management and Business Excellence, vol. 24, no. 11-12, pp. 1364-1375, 2013.

[15] E. Sivadas and R. P. Jindal, "Alternative measures of satisfaction and word of mouth," Journal of Services Marketing, vol. 31, no. 2, pp. 119-130, 2017.

[16] R. Rajaguru and N. Hassanli, "The role of trip purpose and hotel star rating on guests' satisfaction and WOM," International Journal of Contemporary Hospitality Management, vol. 30, no. 5, pp. 2268-2286, 2018.

[17] C. Lu, C. Berchoux, M. W. Marek, and B. Chen, "Service quality and customer satisfaction: qualitative research implications for luxury hotels," International Journal of Culture, Tourism, and Hospitality Research, vol. 9, no. 2, pp. 168182, 2015.

[18] A. Mohsin and T. Lockyer, "Customer perceptions of service quality in luxury hotels in New Delhi, India: an exploratory study," International Journal of Contemporary Hospitality Management, vol. 22, no. 2, pp. 160-173, 2010.

[19] E. N. Torres, "Deconstructing service quality and customer satisfaction: challenges and directions for future research," Journal of Hospitality Marketing and Management, vol. 23, no. 6, pp. 652-677, 2014.

[20] R. Hallak, G. Assaker, and R. El-Haddad, "Re-examining the relationships among perceived quality, value, satisfaction, and destination loyalty: a higher-order structural model," Journal of Vacation Marketing, vol. 24, no. 2, pp. 118-135, 2018.

[21] A. Parasuraman, V. Zeithaml, and L. Berry, "SERVQUAL-a multiple-item scale for measuring consumer perceptions of service quality," Journal of Retailing, vol. 64, no. 1, pp. 1237, 1988

[22] C. Ryan, "Seeking quality in Pacific tourism," in Tourism in the Pacific: Issues and Cases, C. M. Hall and S. J. Page, Eds., pp. 146-160, International Thomson Business Press, London, England, 1996.

[23] G. Prayag, “Tourists' evaluations of destination image, satisfaction, and future behavioral intentions-the case of 
Mauritius," Journal of Travel \& Tourism Marketing, vol. 26, no. 8, pp. 836-853, 2009.

[24] B. Meng and H. Han, "Working-holiday tourism attributes and satisfaction in forming word-of-mouth and revisit intentions: impact of quantity and quality of intergroup contact," Journal of Destination Marketing \& Management, vol. 9, pp. 347-357, 2018.

[25] E. W. Anderson, C. Fornell, and D. R. Lehmann, "Customer satisfaction, market share, and profitability: findings from Sweden," Journal of Marketing, vol. 58, no. 3, p. 53, 1994.

[26] L. C. Cong, "A formative model of the relationship between destination quality, tourist satisfaction and intentional loyalty: an empirical test in Vietnam," Journal of Hospitality and Tourism Management, vol. 26, pp. 50-62, 2016.

[27] R. Ramamoorthy, A. Gunasekaran, M. Roy, B. K. Rai, and S. A. Senthilkumar, "Service quality and its impact on customers' behavioural intentions and satisfaction: an empirical study of the Indian life insurance sector," Total Quality Management \& Business Excellence, vol. 29, no. 7-8, pp. 834-847, 2016.

[28] E. F. Mathis, H. L. Kim, M. Uysal, J. M. Sirgy, and N. K. Prebensen, "The effect of co-creation experience on outcome variable," Annals of Tourism Research, vol. 57, pp. 62-75, 2016.

[29] M. W. Liu and H. T. Keh, "Consumer delight and outrage: scale development and validation," Journal of Service Theory and Practice, vol. 25, no. 6, pp. 680-699, 2015.

[30] H.-H. S. Hu, J. Kandampully, and T. D. Juwaheer, "Relationships and impacts of service quality, perceived value, customer satisfaction, and image: an empirical study," The Service Industries Journal, vol. 29, no. 2, pp. 111-125, 2009.

[31] G. H. G. McDougall and T. Levesque, "Customer satisfaction with services: putting perceived value into the equation," Journal of Services Marketing, vol. 14, no. 5, pp. 392-410, 2000.

[32] J. Alegre and J. Garau, "Tourist satisfaction and dissatisfaction," Annals of Tourism Research, vol. 37, no. 1, pp. 52-73, 2010.

[33] F. Ali, "Service quality as a determinant of customer satisfaction and resulting behavioural intentions: a SEM approach towards Malaysian resort hotels," Tourism, vol. 63, no. 1, pp. 37-52, 2015.

[34] Y. Kim and J. Lee, "Relationship between corporate image and customer loyalty in mobile communications service markets," Africa Journal of Business Management, vol. 4, no. 18, pp. 4035-4041, 2010.

[35] K. Ryu, H.-R. Lee, and W. G. Kim, "The influence of the quality of the physical environment, food, and service on restaurant image, customer perceived value, customer satisfaction, and behavioral intentions," International Journal of Contemporary Hospitality Management, vol. 24, no. 2, pp. 200-223, 2012.

[36] I. R. del Bosque and H. San Martín, "Tourist satisfaction a cognitive-affective model," Annals of Tourism Research, vol. 35, no. 2, pp. 551-573, 2008.

[37] Y. Yoon and M. Uysal, "An examination of the effects of motivation and satisfaction on destination loyalty: a structural model," Tourism Management, vol. 26, no. 1, pp. 4556, 2005.

[38] R. A. Ganiyu, I. I. Uche, and A. O. Elizabeth, "Is customer satisfaction an indicator of customer loyalty?," Australian
Journal of Business and Management Research, vol. 2, no. 7, pp. 14-20, 2012.

[39] K. Ifie, A. C. Simintiras, Y. Dwivedi, and V. Mavridou, "How service quality and outcome confidence drive pre-outcome word-of-mouth," Journal of Retailing and Consumer Services, vol. 44, pp. 214-221, 2018.

[40] M. Hultman, D. Skarmeas, P. Oghazi, and H. M. Beheshti, "Achieving tourist loyalty through destination personality, satisfaction, and identification," Journal of Business Research, vol. 68, no. 11, pp. 2227-2231, 2015.

[41] Y. Wardi, A. Abror, and O. Trinanda, "Halal tourism: antecedent of tourist's satisfaction and word of mouth (WOM)," Asia Pacific Journal of Tourism Research, vol. 23, no. 5, pp. 463-472, 2018.

[42] A. Marchand, T. Hennig-Thurau, and C. Wiertz, "Not all digital word of mouth is created equal: understanding the respective impact of consumer reviews and microblogs on new product success," International Journal of Research in Marketing, vol. 34, no. 2, pp. 336-354, 2017.

[43] M. A. Saleem, A. Yaseen, and A. Wasaya, "Drivers of customer loyalty and word of mouth intentions: moderating role of interactional justice," Journal of Hospitality Marketing and Management, vol. 27, no. 8, pp. 877-904, 2018.

[44] A. M. Baker, N. Donthu, and V. Kumar, "Investigating how word-of-mouth conversations about brands influence purchase and retransmission intentions," Journal of Marketing Research, vol. 53, no. 2, pp. 225-239, 2016.

[45] R. Oliver, "Measurement and evaluation of satisfaction processes in retail settings," Journal of Retailing, vol. 57, no. 3, pp. 25-48, 1981.

[46] A. Pizam, V. Shapoval, and T. Ellis, "Customer satisfaction and its measurement in hospitality enterprises: a revisit and update," International Journal of Contemporary Hospitality Management, vol. 28, no. 1, pp. 2-35, 2017.

[47] S. R. Swanson and M. K. Hsu, "The effect of recovery locus attributions and service failure severity on word-of-mouth and repurchase behaviors in the hospitality industry," Journal of Hospitality \& Tourism Research, vol. 35, no. 4, pp. 511529, 2011.

[48] G. Tripathi, "Customer satisfaction and word of mouth intentions: testing the mediating effect of customer loyalty," Journal of Services Research, vol. 17, no. 2, pp. 1-16, 2018.

[49] M. Amin, Z. Yahya, W. F. A. Ismayatim, S. Z. Nasharuddin, and E. Kassim, "Service quality dimension and customer satisfaction: an empirical study in the Malaysian hotel industry," Services Marketing Quarterly, vol. 34, no. 2, pp. 115-125, 2013.

[50] G. Dominici and R. Guzzo, "Customer satisfaction in the hotel industry: a case study from Sicily," International Journal of Marketing Studies, vol. 2, no. 2, pp. 3-12, 2010.

[51] I. K. W. Lai and M. Hitchcock, "Local reactions to mass tourism and community tourism development in Macau," Journal of Sustainable Tourism, vol. 25, no. 4, pp. 451470, 2016.

[52] E. N. Torres, X. Fu, and X. Lehto, "Are there gender differences in what drives customer delight?," Tourism Review, vol. 69, no. 4, pp. 297-309, 2014.

[53] E. N. Torres and S. Kline, "From customer satisfaction to customer delight: creating a new standard of service for the hotel industry," International Journal of Contemporary Hospitality Management, vol. 25, no. 5, pp. 642-659, 2013. 
[54] J. C. Crotts and V. P. Magnini, "Is Surprise Essential?," Annals of Tourism Research, vol. 38, no. 2, pp. 719-722, 2011.

[55] J. Ma, J. Gao, N. Scott, and P. Ding, "Customer delight from theme park experiences," Annals of Tourism Research, vol. 42, pp. 359-381, 2013.

[56] S. M. C. Loureiro, F. J. Miranda, and M. Breazeale, "Who needs delight?," Journal of Service Management, vol. 25, no. 1, pp. 101-124, 2014.

[57] A. Finn, "Customer delight: distinct construct or zone of nonlinear response to customer satisfaction?," Journal of Service Research, vol. 15, no. 1, pp. 99-110, 2012.

[58] J. Füller and K. Matzler, "Customer delight and market segmentation: an application of the three-factor theory of customer satisfaction on life style groups," Tourism Management, vol. 29, no. 1, pp. 116-126, 2008.

[59] C. H. Chandler, "Quality: beyond customer satisfaction," Quality Progress, vol. 22, no. 30-32, 1989.

[60] B. Berman, "How to delight your customers," California Management Review, vol. 48, no. 1, pp. 129-151, 2005.

[61] M. J. Arnold, K. E. Reynolds, N. Ponder, and J. E. Lueg, "Customer delight in a retail context: investigating delightful and terrible shopping experiences," Journal of Business Research, vol. 58, no. 8, pp. 1132-1145, 2005.

[62] R. T. Rust and R. L. Oliver, "Should we delight the customer?," Journal of the Academy of Marketing Science, vol. 28, no. 1, pp. 86-94, 2000.

[63] M. W. Alexander, "Customer delight: a review," Academy of Marketing Studies Journal, vol. 50, no. 5, pp. 535-545, 2010.

[64] S. Denning, "The essential metric of customer capitalism is customer outcomes," Strategy \& Leadership, vol. 39, no. 4, pp. 12-18, 2011.

[65] R. Oliver and W. S. DeSarbo, "Processing of the satisfaction response in consumption: a suggested framework and research propositions," Journal of Consumer Satisfaction, Dissatisfaction and Complaining Behavior, vol. 2, no. 1, pp. 1-16, 1989.

[66] E. N. Torres and S. Kline, "From satisfaction to delight: a model for the hotel industry," International Journal of Contemporary Hospitality Management, vol. 18, no. 4, pp. 290301, 2006.

[67] J. L. H. Bowden and T. S. Dagger, "To delight or not to delight? An investigation of loyalty formation in the restaurant industry," Journal of Hospitality Marketing \& Management, vol. 20, no. 5, pp. 501-524, 2011.

[68] F. Ali, W. G. Kim, J. Li, and H.-M. Jeon, "Make it delightful: customers' experience, satisfaction and loyalty in Malaysian theme parks," Journal of Destination Marketing \& Management, vol. 7, pp. 1-11, 2018.

[69] Gloria Thalasso \& Hotels, Thalasso Gloria-San Agustín, 2016, July 2016, http://www.gloriapalaceth.com/hoteles/ gloria-palace-san-agustin-thalasso-hotel/thalasso/.

[70] R. Sierra Bravo, Técnicas de investigación social. Teoría y ejercicios, Paraninfo, Madrid, 1991.

[71] HuangSongshan (Sam), A. Afsharifar, and R. van der Veen, "Examining the moderating role of prior knowledge in the relationship between destination experiences and tourist satisfaction," Journal of Vacation Marketing, vol. 22, no. 4, pp. 320-334, 2016.

[72] I. P. Riquelme, S. Román, and D. Iacobucci, "Consumers' perceptions of online and offline retailer deception: a moderated mediation analysis," Journal of Interactive Marketing, vol. 35, pp. 16-26, 2016.

[73] Y. Rosseel, "Lavaan: an R package for structural equation modeling," Journal of Statistical Software, vol. 48, no. 2, pp. 1-36, 2012.

[74] E. Alfaro, M. Gamez, and N. García, “Adabag: an R package for classification with boosting and bagging," Journal of Statistical Software, vol. 54, no. 2, pp. 1-35, 2013.

[75] L. Y. Leong, T. S. Hew, V. H. Lee, and K. B. Ooi, “An SEMartificial-neural-network analysis of the relationships between SERVPERF, customer satisfaction and loyalty among low-cost and full-service airline," Expert Systems with Applications, vol. 42, no. 19, pp. 6620-6634, 2015.

[76] A.-C. Teo, G. W.-H. Tan, K.-B. Ooi, T.-S. Hew, and K.-T. Yew, "The effects of convenience and speed in m-payment," Industrial Management \& Data Systems, vol. 115, no. 2, pp. 311-331, 2015.

[77] J. F. Hair, W. Black, and B. Balbin, Multivariate Data Analysis: A Global Perspective, Prentice Hall, Upper Saddle River, NJ, USA, 7th ed. edition, 2010.

[78] L. Y. Leong, T. S. Hew, G. W. H. Tan, and K. B. Ooi, "Predicting the determinants of the NFC-enabled mobile credit card acceptance: a neural networks approach," Expert Systems with Applications, vol. 40, no. 14, pp. 5604-5620, 2013.

[79] C.-J. Wang, H.-T. Tsai, and M.-T. Tsai, "Linking transformational leadership and employee creativity in the hospitality industry: the influences of creative role identity, creative self-efficacy, and job complexity," Tourism Management, vol. 40, pp. 79-89, 2014.

[80] M. K. Cabrera-Suárez, M. D. L. C. Déniz-Déniz, and J. D. Martín-Santana, "The setting of non-financial goals in the family firm: the influence of family climate and identification," Journal of Family Business Strategy, vol. 5, no. 3, pp. 289-299, 2014.

[81] F. T. S. Chan and A. Y. L. Chong, "A SEM-neural network approach for understanding determinants of interorganizational system standard adoption and performances," Decision Support Systems, vol. 54, no. 1, pp. 621-630, 2012.

[82] K. K. F. So, C. King, B. A. Sparks, and Y. Wang, "The role of customer engagement in building consumer loyalty to tourism brands," Journal of Travel Research, vol. 55, no. 1, pp. 64-78, 2015.

[83] J. C. Anderson and D. W. Gerbing, "Structural equation modeling in practice: a review and recommended two-step approach," Psychological Bulletin, vol. 103, no. 3, pp. 411423, 1988.

[84] J. F. Hair, G. T. Hult, C. M. Ringle, and M. Sarstedt, A Primer on Partial Least Squares Structural Equation Modeling (PLSSEM), SAGE, Thousand Oaks CA, USA, 2014.

[85] J. L. Roldán and M. J. Sánchez-Franco, "Variance-based structural equation modeling: guidelines for using partial least squares in information systems research," in Research Methodologies, Innovations and Philosophies in Software Systems Engineering and Information Systems, M. Mora, A. Steenkamp, L. Johnston, and J. Gamon, Eds., pp. 193221, Information Science Reference, Hershey, PA, USA, 2012.

[86] C. Fornell and D. F. Larcker, "Evaluating structural equation models with unobservable variables and measurement error," Journal of Marketing Research, vol. 18, no. 1, pp. 39-50, 1981. 
[87] W. W. Chin, "Issues and opinion on structural equation modeling," MIS Quarterly, vol. 22, no. 1, pp. 7-16, 1998.

[88] P. Bertea and A. Zait, "Methods for testing discriminant validity," Management \& Marketing Journal, vol. 9, no. 2, pp. 217-224, 2011.

[89] J. Henseler, C. M. Ringle, and M. Sarstedt, "A new criterion for assessing discriminant validity in variance-based structural equation modeling," Journal of the Academy of Marketing Science, vol. 43, no. 1, pp. 115-135, 2015.

[90] J. F. Hair, G. T. M. Hult, C. Ringle, and M. Sarstedt, $A$ Primer on Partial Least Squares Structural Equation Modeling (PLS-SEM), SAGE Publications, Thousand Oaks, CA, USA, 2016.

[91] A. Satorra, "Power of $\chi^{2}$ goodness-of-fit test in structural equation models: the case of non-normal data," in New Developments of Psychometrics, H. Yanai, A. Okada, K. Shigemasu, Y. Kano, and J. Meulman, Eds., pp. 57-68, Springer, Tokyo, 2003.

[92] A. Satorra and P. M. Bentler, "A scaled difference chi-square test statistic for moment structure analysis," Psychometrika, vol. 66, no. 4, pp. 507-514, 2001.

[93] E. Bauer and R. Kohavi, "An empirical comparison of voting classification algorithms: bagging, boosting, and variants," Machine Learning, vol. 36, no. 1/2, pp. 105-139, 1999.

[94] T. G. Dietterich, "Ensemble methods in machine learning," in Multiple Classifier Systems, pp. 1-15, Springer, Berlin, Heidelberg, 2000.

[95] M. Galar, A. Fernandez, E. Barrenechea, H. Bustince, and F. Herrera, "A review on ensembles for the class imbalance problem: bagging-, boosting-, and hybrid-based approaches," IEEE Transactions on Systems, Man, and Cybernetics, Part C (Applications and Reviews), vol. 42, no. 4, pp. 463-484, 2012.

[96] S. B. Kotsiantis, "Supervised machine learning: a review of classification techniques," Informatica, vol. 31, pp. 249-268, 2007.

[97] T. G. Dietterich, "An experimental comparison of three methods for constructing ensembles of decision trees," Machine Learning, vol. 40, no. 2, pp. 139-157, 2000.

[98] M. Chrzanowska, E. Alfaro, and D. Witkowska, "The individual borrowers recognition: single and ensemble trees," Expert Systems with Applications, vol. 36, no. 3, pp. 6409-6414, 2009.

[99] M. A. King, A. S. Abrahams, and C. T. Ragsdale, "Ensemble learning methods for pay-per-click campaign management," Expert Systems with Applications, vol. 42, no. 10, pp. 48184829, 2015.

[100] A.-H. Homaie-Shandizi, V. P. Nia, M. Gamache, and B. Agard, "Flight deck crew reserve: from data to forecasting," Engineering Applications of Artificial Intelligence, vol. 50, pp. 106-114, 2016.

[101] J. N. Morgan and J. A. Sonquist, "Problems in the analysis of survey data, and a proposal," Journal of the American Statistical Association, vol. 58, no. 302, pp. 415-434, 1963.

[102] L. Breiman, J. Friedman, R. Olshen, and C. Stone, Classification and Regression Trees, Wadsworth \& Brooks, Wadsworth International Group, Monterey, CA, USA, 1984.

[103] C. F. Tsai and Y. J. Chiou, "Earnings management prediction: a pilot study of combining neural networks and decision trees," Expert Systems with Applications, vol. 36, no. 3, pp. 7183-7191, 2009.

[104] G. Shmueli, N. Patel, and P. Bruce, Data Mining for Business Intelligence: Concepts, Techniques, and Applications in
Microsoft Office Excel with XLMiner, Wiley, Hoboken, N.J, USA, 2010.

[105] A. P. Bradley, "The use of the area under the ROC curve in the evaluation of machine learning algorithms," Pattern Recognition, vol. 30, no. 7, pp. 1145-1159, 1997.

[106] D. G. Altman and J. M. Bland, "Statistics notes: diagnostic tests 1: sensitivity and specificity," BMJ, vol. 308, no. 6943, article 1552, 1994.

[107] S. Gopinath, P. K. Chintagunta, and S. Venkataraman, "Blogs, advertising, and local-market movie box office performance," Management Science, vol. 59, no. 12, pp. 2635-2654, 2013. 


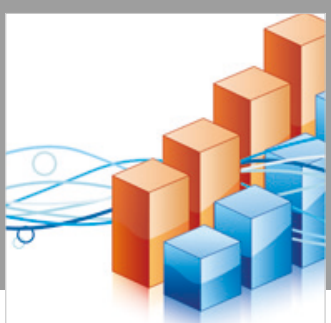

Advances in

Operations Research

\section{-n-m}
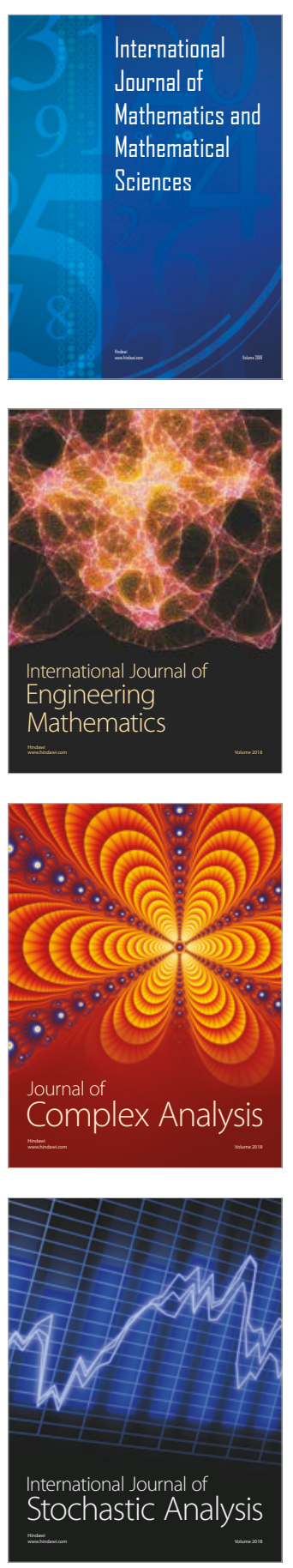
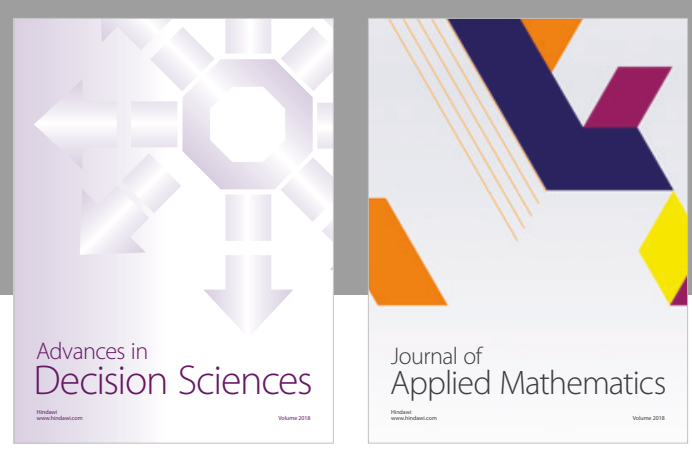

Journal of

Applied Mathematics
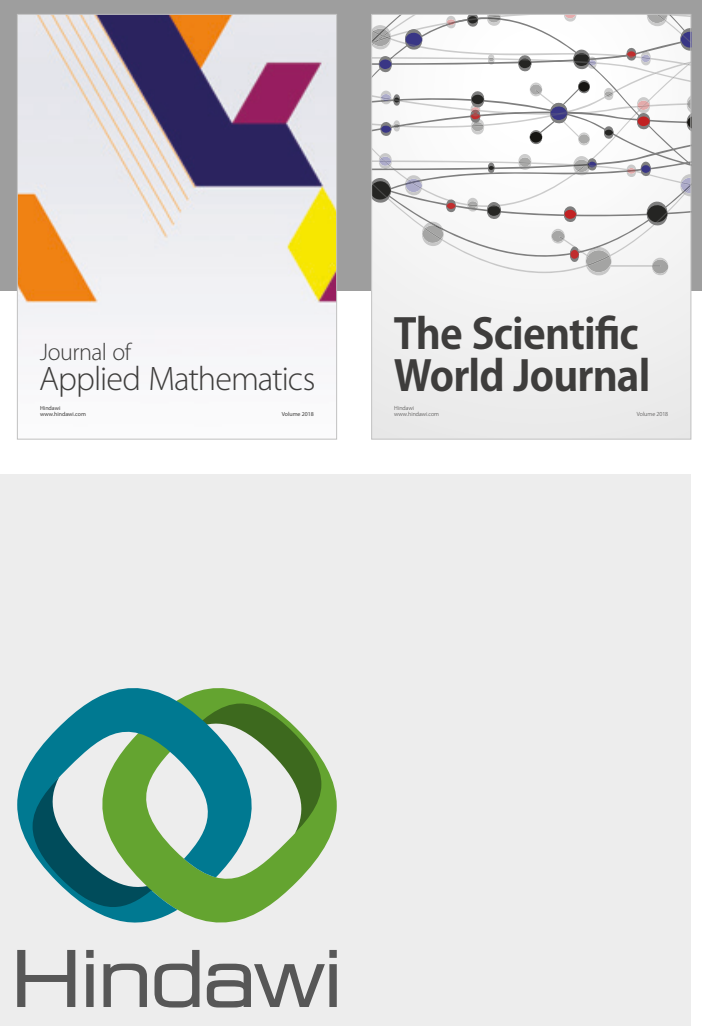

Submit your manuscripts at

www.hindawi.com

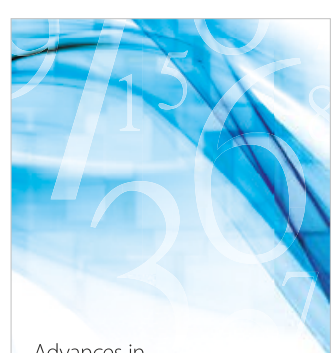

Advances in
Numerical Analysis
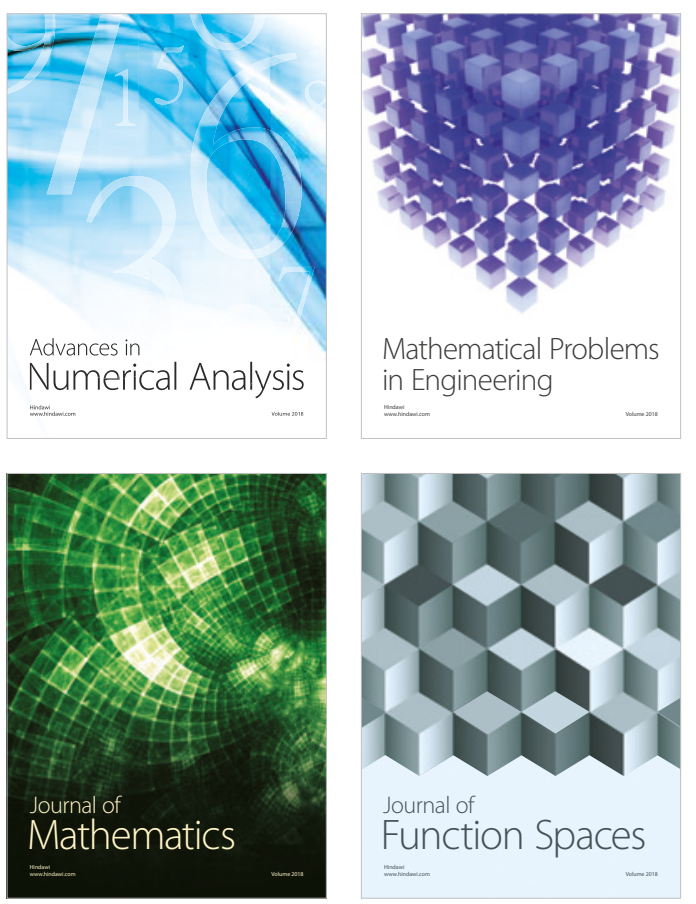

Mathematical Problems in Engineering

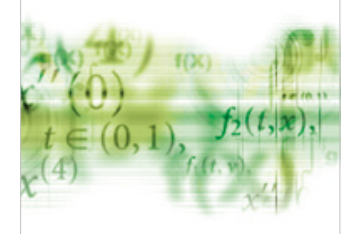

International Journal of

Differential Equations

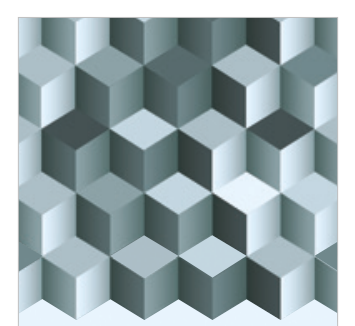

Journal of

Function Spaces
The Scientific

World Journal

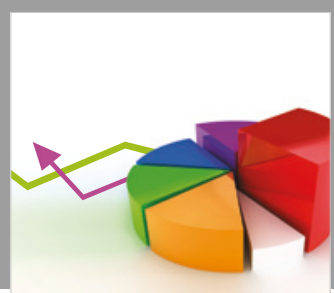

Journal of

Probability and Statistics
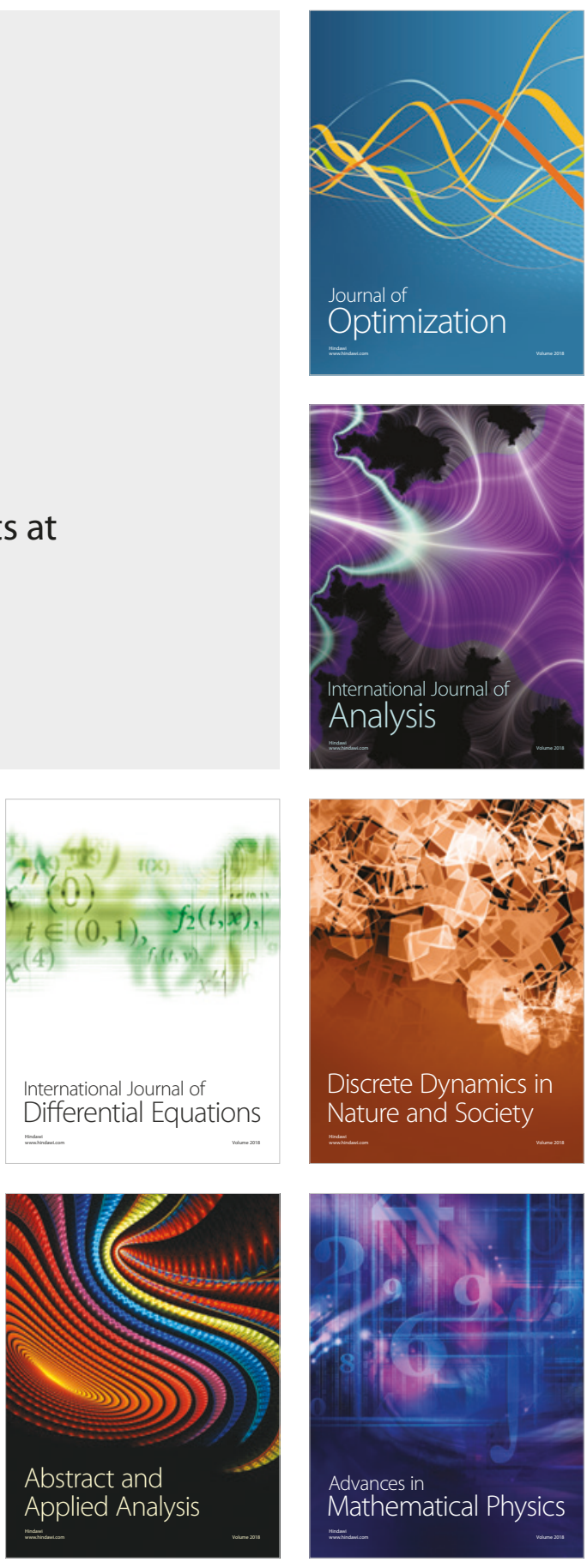